\title{
Elazığ yöresinde meşe ekimlerinin gelişimi ile bazı yetişme ortamı özellikleri arasındaki ilişkiler
}

\author{
Relationship between growth performance of oak seedlings and site characteristics in \\ Elazığ province of Turkey
}

\author{
Bahri KALKAN ${ }^{1}$ \\ Hidayet KARAKURT ${ }^{2}$ \\ Kürşad ÖZKAN ${ }^{3}$ \\ Osman TIRYAK $\dot{I}^{4}$ (iD \\ Özden GÜNEŞ ${ }^{1}$
}

\footnotetext{
${ }^{1}$ Güney Doğu Anadolu Ormancılık Araştırma Enstitüsü Müdürlüğü, Elazığ

${ }^{2}$ Kavak ve Hızlı Gelişen Orman Ağaçları Araştırma Enstitüsü Müdürlüğü, İzmit

${ }^{3}$ Isparta Uygulamalı Bilimler Üniversitesi, Orman Fakültesi, Isparta

${ }^{4}$ Amasya Orman Bölge Müdürlüğü, Tokat Orman İşletme Müdürlüğü, Tokat
}

Sorumlu yazar (Corresponding author) Bahri KALKAN

bahrikalkan@ogm.gov.tr

Geliş tarihi (Received)

27.04.2020

Kabul Tarihi (Accepted)

28.08.2020

Sorumlu editör (Corresponding editor) Ali KAVGACI

alikavgaci1977@yahoo.com

Atıf (To cite this article): Kalkan, B, Karakurt, $\mathrm{H}$ , Özkan, K, Tiryaki, O, Güneş, Ö . (2021). Elazığ yöresinde meşe ekimlerinin gelişimi ile bazı yetişme ortamı özellikleri arasındaki ilişkiler . Ormancılık Araştırma Dergisi , 8 (1) , 27-41 . DOI: 10.17568/ogmoad.724369

Creative Commons Atıf . Cüretilemez 4.0 Utuslaf Lisansı ile lisanslanmıştır.

\section{Öz}

Elâzı ̆̆ ve çevresinde, 1998 yılında toprak muhafaza amacı ile yap1lan meşe ekimlerinin gelişimi ile bazı yetişme ortamı özellikleri arasındaki ilişkinin açığa çıkarılması amaçlanmıştır. Bunun için farklı yükselti, bak1, eğim ve yamaç konumuna göre dağılımları homojen yapılmış 20x20 m ebadında 54 adet örnekleme alanı belirlenmiştir. $\mathrm{Bu}$ örnekleme alanlarında tüm fertlerin tür teşhisleri yapılmış ve aynı yaşlı olduklarını teyit etmek için her örnekleme alanında iki fert dipten kesilmiştir. 51 adet örnek alanında türlerin boy ve dip çap ölçümleri yapılmış, açılan toprak profillerinden derinlik kademesine göre bozulmuş ve bozulmamış toprak örnekleri alınmıştır. Meşe ekimi yapılmış ancak başarısız olunmuş üç adet örnek alanda ise başarısızlığın toprak özellikleri ile ilişkili olup olmadığını tespit etmek amacıyla sadece toprak örnekleri alınmıştır. Elde edilen veriler sınıflandırma ve regresyon ağacı yöntemi (STRAT) ile analiz edilmiştir. Modelleme DTREG programı kullanılarak gerçekleştirilmiştir. İstatistik analiz sonuçlarına göre, Elâzığ ve çevresinde ekimle yetiştirilen Quercus brantii L. (İran palamut meşesi) ve Quercus cerris L. (saçlı meşe) türlerinin çap artımı ve boy büyüme performansı üzerinde, yetişme ortamı özellikleri (Eğim, bakı, rakım, anakaya) ve toprak özellikleri (rezerve kum, kil ve organik karbon içeriği, mutlak toprak derinliği) etkili olmuştur.

Anahtar Kelimeler: Meşe, büyüme performansı, yetişme ortamı özellikleri

\section{Abstract}

To reveal the relationship between growth performance of oak seedlings planted for the soil conservation in Elâzığ province, in 1998, and some site characteristics the research was established. Fifty-four sample plots, which were $20 \times 20 \mathrm{~m}$ size, were determined homogeneously according to different altitude, aspect, slope degree and slope position. Identification of oak species of all individuals was made in these sample plots, and two individuals were cut at the root collar to confirm that they were at an even age. Height and root collar diameter measurements of the tree species were carried out in 51 sample plots, disturbed and undisturbed soil samples were taken from soil profiles from different depths. In three plots where oak seedlings could not survive, only soil samples were taken to determine whether the failure was related to the soil characteristics. The collected data were analyzed by the classification and regression tree technique with DTREG software. According to the statistical analysis results, the site characteristics (slope, aspect, altitude, parent material) and soil properties (stored sand and clay, topsoil (solum) depth and organic carbon content) were effective on diameter and height growth performance of Quercus brantii L. (Persian oak) and Q. cerris L. (Turkey oak) species which were directly sown to the soil in Elâzığ province.

Keywords: Quercus sp., growth performance, site properties 


\section{Giriş}

Küresel ısınma ve iklim değişikliğinin bir sonucu olarak dünya üzerinde bazı bölgelerin daha da kuraklaşacağı, bazı türlerin yayılış alanlarının daralacağ 1 öngörülmektedir (Eilmann ve ark., 2009). Son zamanlarda Elâzığ ili ve çevresinde önceki yıllarda yapılmış ibreli ağaçlandırmalarda toplu kurumaların meydana geldiği görülmektedir. Bu alanlarda yapılan incelemelerde; değişik yaşlı ibreli türlerin üst üste yaşanan kuraklıklardan etkilenerek strese girdikleri, sağlıksız fertlerin mantar veya böcek zararı sonucu kurudukları, ancak aynı alanda mevcut asli tür meşelerde ise herhangi bir sorun yaşanmadığı görülmektedir (Kalkan ve ark., 2020). Elâzı̆̆ ili ve çevresinde fidan yetiştirme açısından iklim ve toprak özellikleri bakımından birçok olumsuzluğun bulunması ve önümüzdeki yıllarda küresel ısınmanın devam edeceği göz önüne alındığında, asli tür olan meşe ile yapılacak ağaçlandırmaların önem kazanacağı düşünülmektedir. Elâzığ ili ve çevresinde, 1998 yılında yapılmış meşe palamudu ekimlerinin 18 yıl sonra yetişme ortamı özellikleri bakımından değerlendirilmesi, elde edilen bulguların uygulamaya aktarılması, gelecekte küresel ısınma nedeni ile ortaya çıkabilecek olumsuzluklara ön hazırlık bakımından da önem taşımaktadır.

Ağaçlarda büyüme araștırmaları, orman bilimi ve ormancılıkta uzun bir geçmişe sahiptir. İlk sistematik araştırmalar, çeşitli yetişme ortamı koşullarında boy büyümesine odaklanmış ve 19. yüzyılın başlarında meşcere bonitet (verimlilik) tabloları şeklinde ortaya çıkmıştır (Tesch, 1981). Daha sonra, genellikle tekrarlanan çap ölçümleri veya ağaç yıllık halkaları temelinde çalışılan çap büyümesine artan bir ilgi gelişti. Gerçekten, ağaç yıllık halkalarının sistematik olarak incelenmesi, orman bilimlerinin önemli bir dalı olarak dendrokronolojiyi yaratmış (Douglass, 1941; Stokes ve Smiley, 1968; Fritts, 1976), bu çabaların hepsi birlikte bazı genel büyüme itici güçleri hakkında fikir birliği sağlamış: iklim değişkenliğinin ağaç büyümesini (Fritts, 1976) güçlü bir şekilde etkilediği, fakat aynı zamanda toprak özellikleri, bakı ve eğim gibi topografik özelliklerinde etkisi olduğu hakkındaki araştırma sonuçları kabul görmüştür (Oberhuber ve Kofler, 2000; Weber ve ark., 2007). Bununla birlikte, sadece meşe türünde değil çoğu ağaç türünde bu etkilerin ve etkileşimlerinin oranları hakkındaki bilgiler büyük ölçüde eksiktir (Rohner, 2012). Türkiye'deki meşelerin yetiştikleri ortamın; iklim, yeryüzü şekli, anakaya / toprak özellikleri, 1şık ve besin maddesi istekleri, diğer ağaç ve çalı türleri ile bir arada yaşamaları vs. ilişkileri hakkında kapsamlı araştırmalar gerekmektedir (Kantarc1, 2010).
Bu çalışmada, Elâzı̆̆ ili ve çevresinde gerçekleştirilen toprak muhafaza çalışmalarında yaygın olarak kullanılan ve bu yörenin asli ağacı olan iki meşe türünün yetişme ortamı özellikleri bakımından iyi gelişim gösterdiği şartları ortaya çıkarmak, uygulayıcıların palamut ekimi yapılacak ağaçlandırma saha seçimlerinde dikkat edeceği yetişme ortamı özellikleri konusunda rehberlik etmek amaçlanmıştır. Ayrıca, yetişme ortamı özelliklerinin meşe fidanlarının gelişimi üzerinde etkisinin olup olmadığ 1 ve etki var ise yetişme ortamı özellikleri arasındaki farklılıkların ortaya çıkarılması hedeflenmiştir.

\section{Materyal ve Yöntem}

\subsection{Materyal}

Çalışmanın materyalini, Elâzı̆̆ ili, Baskil ilçesi Harabakayış ve Sivrice ilçesi Kavak mikro havza (MH) projeleri kapsamında, 1998 yılında meşe ekimi yapılmış, 20x20 m ebadında 54 adet örnekleme alanından alınan 179 adet toprak örneği, 4.382 ocakta yer alan 8.461 fertte yapılmış dip çap ve boy ölçümleri oluşturmaktadır.

\subsubsection{Araștırma alanın tanıtımı}

\subsubsection{Baskil- Harabakayış köyü (yarı kurak iklim bölgesi)}

Baskil ilçesi sınırları içerisinde yer alan Harabakayış köyü Elâzığ ilinin batısında yer almaktadır. Örnek alanların rakımı 1.346-1.646 m ve genel bakısı güneydir. Örnekleme alanlar1 38 $31^{\prime} 30^{\prime \prime}-38^{0} 31^{\prime} 45^{\prime}$ " kuzey enlemleri ile 38042'26'-38 $48^{\circ} 36^{\prime}$ ' doğu boylamları arasında yer almaktadır.

Örnekleme alanlarına en yakın Baskil İlçesi Meteoroloji İstasyonun 1979-2005 yilları arasındaki kayıtlarına göre yıllık yağış miktarı 427,3 mm, ortalama yüksek sicaklık $17,7^{\circ} \mathrm{C}$ 'dir. Thornthwaite yöntemine göre iklim tipi "C1 B'2 d b'3", yarı kurak, yarı nemli, orta sıcaklıkta (mezotermal), su fazlası kış mevsiminde ve orta derecede olan, denizsel iklimine yakın iklimdir. Thornthwaite yöntemiyle oluşturulan su bilançosuna göre (Şekil 1), haziran ayından itibaren 5 ay boyunca su noksanı bulunmaktadir.

Örnekleme alanlarının bulunduğu yörenin jeolojik yapısı Baskil magmatitleri, bu magmatitlerin derinlik kayaçları ise Baskil graniti olarak adlandırılmıştır (Asutay, 1985). Örnekleme alanlarının bulunduğu yörenin toprakları kahverengi orman topraklarıdır. Kurak iklim, yüksek eğim ve seyrek bitki örtüsü sonucu oluşan erozyon nedeni ile toprakta aşınma fazladır. Toprakların şiddetli aşınması nedeni ile yamaç arazilerde her yıl taşınma mey- 


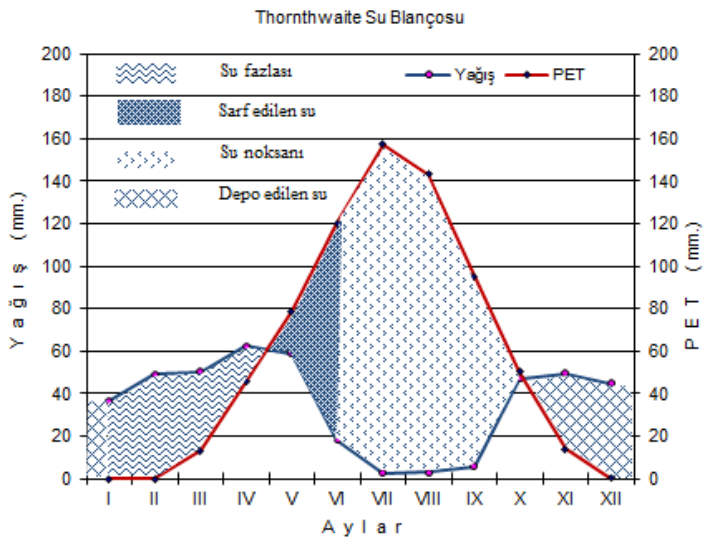

Şekil 1. Baskil-Harabakayış mikro havzasına ait su bilançosu.

Figure 1. The Thornthwaite water balance for BaskilHarabakayış microcatchment

dana gelmekte bunun sonucunda toprak profilinde horizonlaşma ya hiç görülmemekte ya da belirgin olmamaktadır. Bu gibi yerlerde toprak üzerinde anakayanın etkisi artmaktadır.

\subsubsection{Sivrice- Kavak köyü (yarı nemli iklim bölgesi)}

Sivrice ilçesi sınırlarında kalan Kavak köyü Elâzığ ilinin güneyinde yer almaktadır. Örnekleme alanlarının rakımı 1.607-1.830 m ve genel bakısı kuzey doğudur. Örnekleme alanları $38^{\circ} 23^{\prime} 25^{\prime \prime}-38^{\circ} 24^{\prime} 33^{\prime \prime}$ kuzey enlemleri ile $39^{\circ} 08^{\prime} 13^{\prime \prime}-39^{\circ} 10^{\prime} 19^{\prime \prime}$ doğu boylamları arasında yer almaktadır.

Örnekleme alanlarına en yakın Sivrice İlçesi Meteoroloji İstasyonunun 1979-2005 yılları arasındaki kayıtlarına göre yıllık yağış ortalaması 603,2 mm, ortalama sicaklık $10,09^{\circ} \mathrm{C}$ 'dir. Thornthwaite yöntemine göre belirlenen iklim tipi "C2 B'2 s2 b'2", yarı nemli, orta sicaklıkta (mezotermal) su noksanı yaz mevsiminde ve kuvvetli olan, hafif denizsel iklime yakın iklimdir". Thornthwaite yöntemiyle oluşturulan su bilançosuna göre (Şekil 2), haziran ayından itibaren 5 ay boyunca su noksanı bulunmaktadır.

Beyarslan (1996)' a göre, Elâzı̆̆ ili Sivrice ilçesi, Kavak, Kösebayır ve Kamışlık civarının jeolojisini; 1- Paleozoyik-Mezoyik yaşlı Pütürge metamorfitleri, 2- Kretase yaşlı Kömürhan ofiyolitleri, 3- Üst kretase yaşlı Elazı̆ Mağmatitleri, 4- Orta eosen yaşlı Maden karmaşı̆̆ı, 5- Tersiyer yaşlı Kırkgeçit formasyonu, 6- Kuvaterner yaşlı alüvyonlar olmak üzere 6 farklı birimin yüzeylediğini belirtmiștir. Serpantin ve Diyabaz anakayasının hakim olduğu deneme alanlarında yüzeysel ve profil taşlılığı göze çarpmaktadır. Örnekleme alanlarının bulunduğu yörenin toprakları kahverengi orman topraklarıdır.

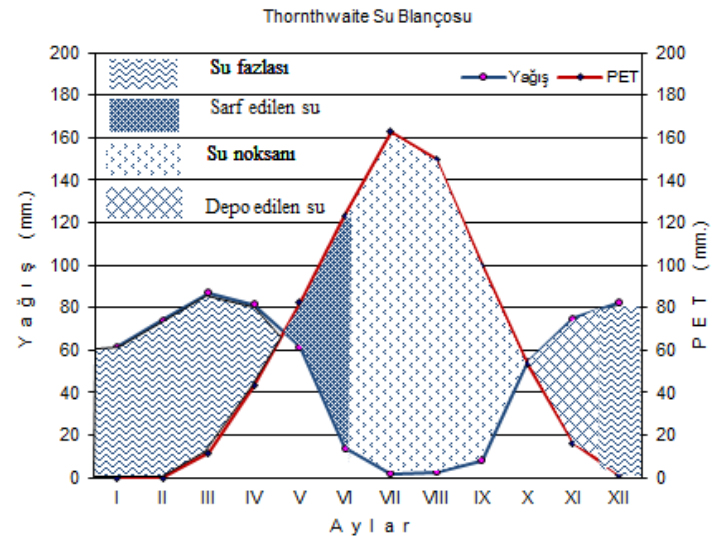

Şekil 2. Sivrice-Kavak mikro havzasına ait su bilançosu.

Figure 2. The Thornthwaite water balance for SivriceKavak microcatchment

\subsection{Yöntem}

\subsubsection{Arazi çalışmaları}

\subsubsection{1. Örnekleme alanlarının seçimi}

Elâzığ ili, Baskil ilçesi sınırları dahilinde bulanan Harabakayış mikro havzasında, 1998 yılında başlayan faaliyetlerle toplam 320 ha (185 ha makineli, 135 ha işçi gücü ile toprak işleme) alanda 21.000 $\mathrm{kg}$ meşe tohum ekimi gerçekleştirilmiştir. Elâzığ ili Sivrice ilçesinde bulunan Kavak mikro havzasında 1998 yılında faaliyete başlanmış ve toplamda 566 ha (320 ha makineli, 246 ha işçi gücü ile toprak işleme) alanda $34.000 \mathrm{~kg}$ meşe tohum ekimi gerçekleştirilmiştir. Kavak ve Harabakayış mikro havzalarında yapılan toprak işleme, tohum ekim ve bakım yöntemleri aynı olup, kullanılan tohum kaynağ1 (Diyarbakır ili Çüngüş ilçesi ve Karacadağ yöresi) ortaktır.

Yapılan toprak işlemelerinde mevcut meşe ağaçlarına dokunulmamış, toprağın tamamen savunmasız olduğu alanlarda, \%40-45 eğime kadar paletli traktörle, daha üst eğimlerde işçi gücü ile yapılan teraslar ile önlem alınmıştır. Paletli traktör (dozer) ile yapılan toprak işlemeleri tam alanda kaz ayağ1 takılı 3'lü riper ile gerçekleştirmiş, bu 3'lü riperin ortası boş bırakılarak, 2 riper izinde 2 m'de bir açılan çizgilere $5-7 \mathrm{~cm}$ derinliğinde 3 meşe tohumu atılmak suretiyle ekim gerçekleştirilmiştir. İşçi terasları yamaçtan aşığı doğru $2 \mathrm{~m}$ düşey aralıkta yapılmış, teras üzerinde ise 1,5 m'de bir açılan çizgilere ekimler gerçekleştirilmiştir. Ocaklar arasında $2 \times 1,5 \mathrm{~m}$ aralık mesafe verilmeye gayret edilmiş, ancak piketaj yapılmamıştır. Sonbaharda ekimi yapılan meşe tohumlarının mayıs sonu, haziran başı çimlenmelerini müteakip başlamak üzere 3 yıl boyunca fidan çevrelerinde ot alma ve çapalama 
şeklindeki bakım işlemi gerçekleştirilmiştir.

Örnekleme alanları makineli toprak işleme yapılan (eğimi \%0-45 olan) sahalardan seçilmiştir. Toplam 51 örnekleme alanı seçilirken eğim, bakı, rakım ve yamaç konumunun homojen (eşit sayıda) olmasına gayret edilmiştir (Tablo 1). Bu örnekleme alanlar1na ilaveten 3 örnekleme alanı $(9,15,32$ nolu örnek alanı) meşe palamudu ekimi yapılmış ancak başarısız olunmuş ağaçlandırma sahalarından seçilmiştir. Bu üç örnekleme alanında sadece toprak analizi yapılmıştır.
Örnekleme alanlar1 20x20 m = $400 \mathrm{~m}^{2}$ büyüklüğünde alınmıştır. Örnek alanların eğimi klizimetre, yükselti, bakı ve koordinatlar coğrafi yer belirleme aleti (GPS) ile belirlenmiş; sonuçlar, 1/25.000 ölçekli eşyükselti eğrili harita ile kontrol edilmiştir. Yeryüzü şekli (yamaç konumu) ise bir yamacın üst kısmındaki sırt çizgisi ile etek kısmı arasındaki yamaç uzunluğu 100 birim kabul edilmiş, yamaç üst kenarından olan ortalama uzaklık yamaç uzunluğunun yüzdesi olarak hesaplanmıştır (Zech ve Çepel, 1972).

Tablo 1. Örnekleme alanlarının dağılımı

Table 1. Distribution of sampling plots

\begin{tabular}{|c|c|c|c|c|c|c|c|c|}
\hline \multirow{2}{*}{$\begin{array}{l}\text { Örnek } \\
\text { Alan }\end{array}$} & \multicolumn{7}{|c|}{ Yükselti (m) } & \multirow{2}{*}{ Toplam } \\
\hline & $1300-1400$ & $1401-1499$ & \multicolumn{2}{|c|}{$1500-1600$} & $1601-1700$ & \multicolumn{2}{|c|}{$1701-1850$} & \\
\hline Adet & 7 & 12 & \multicolumn{2}{|c|}{11} & 12 & \multicolumn{2}{|c|}{9} & 51 \\
\hline$\%$ & 13,7 & 23,5 & \multicolumn{2}{|c|}{21,5} & 23,5 & \multicolumn{2}{|c|}{17,6} & 100 \\
\hline \multirow[b]{2}{*}{$\begin{array}{l}\text { Örnek } \\
\text { Alan }\end{array}$} & \multicolumn{7}{|c|}{ Eğim (\%) } & \\
\hline & $\begin{array}{l}\text { Düz } \\
(1-3)\end{array}$ & $\begin{array}{c}\mathrm{Az} \\
\text { Eğimli } \\
(4-9)\end{array}$ & $\begin{array}{l}\text { Orta eğimli } \\
(10-17)\end{array}$ & $\begin{array}{l}\text { Çok Eğimli } \\
(18-36)\end{array}$ & $\begin{array}{l}\text { Dik eğimli } \\
(37-58)\end{array}$ & & $\begin{array}{l}\mathrm{p} \\
00)\end{array}$ & Toplam \\
\hline Adet & 8 & 11 & 4 & 24 & 4 & & & 51 \\
\hline$\%$ & 15,7 & 21,5 & 7,8 & 47 & 7,8 & & & 100 \\
\hline \multirow{2}{*}{$\begin{array}{l}\text { Örnek } \\
\text { Alan }\end{array}$} & \multicolumn{7}{|c|}{ Yamaç Konumu (\%) } & \multirow{2}{*}{ Toplam } \\
\hline & Sirt (0) & Üst Yamaç & \multicolumn{2}{|c|}{ Orta Yamaç } & Alt Yamaç & \multicolumn{2}{|c|}{ Etek düzlük } & \\
\hline Adet & \multirow[t]{2}{*}{--} & 17 & \multicolumn{2}{|c|}{17} & 17 & \multirow{2}{*}{\multicolumn{2}{|c|}{--}} & 51 \\
\hline$\%$ & & 33,3 & & 3,3 & 33,3 & & & 100 \\
\hline \multirow{3}{*}{$\begin{array}{l}\text { Örnek } \\
\text { Alan }\end{array}$} & \multicolumn{7}{|c|}{ Bak1 } & \\
\hline & \multicolumn{3}{|c|}{ Gölgeli Bakılar } & \multicolumn{4}{|c|}{ Güneşli Bakılar } & Toplam \\
\hline & $\mathrm{KD}$ & $\mathrm{KB}$ & $\mathrm{D}$ & GD & $\mathrm{G}$ & GB & $\mathrm{B}$ & \\
\hline Adet & 3 & 8 & 15 & 11 & 9 & 3 & 1 & 51 \\
\hline$\%$ & 5,8 & 15,7 & 29,4 & 21,5 & 17,6 & 5,9 & 1,9 & 100 \\
\hline
\end{tabular}

\subsubsection{2. Örnekleme alanlarında yer alan meșe ağaçlarında tür ve yaş tespiti}

Örnekleme alanlarındaki ağaçlarda türlerin tespiti Yaltırık (1984)'a göre yapılmıştır. Quercus brantii L. (İran palamut meşesi) tüm örnekleme alanlarında mevcut iken, Quercus cerris L. (saçlı meşe) 32 örnekleme alanında görülmüştür.

Örnekleme alanlarındaki meşe ağaçlarının yaş tespiti ise alan içindeki 1-2 ferdin toprağın biraz altında olmak üzere kesilmesi ve yıllık halkalarının sayımı ile yapılmıştır. Örnekleme alanları seçilirken fertlerin aynı yaşlı olmasına dikkat edilmiş, 2017 sonbaharı itibariyle örnek alanlardaki fertlerin yaşları 18 olarak ölçülmüştür.

\subsubsection{3. Örnekleme alanlarındaki ağaçların boy ve çap ölçümleri}

Örnekleme alanlarındaki ağaçların boyları boy ölçme latası ile $(\mathrm{cm})$, çapları ise dijital çap ölçer aleti ile $(\mathrm{cm})$ ölçülerek kayıt altına alınmıştır. 20×20 m $=400 \mathrm{~m}^{2}$ 'lik gözlem alanlarında bulunan Quercus brantii L. ve $Q$. cerris L. fertlerinin ayrı ayrı dip çap ve boyları arazide ölçülmüştür. 51 örnekleme alanında 4.382 ocakta, 7.210 adet İran palamut meşesi, 1.251 adet saçlı meşe olmak üzere toplam 8.461 adet ferdin boy ve çap ölçümleri yapılmıştır.

\subsubsection{4. Örnekleme alanlarında toprak örneklerinin alınması}

54 adet örnekleme alanında 1 adet $120 \mathrm{~cm}$ derin- 
liğinde, mutlak derinliğin 120 cm'e ulaşmadığ örnekleme alanlarında ise mutlak derinlik kadar toprak profili açılmış, 0-30, 30-60, 60-90 ve 90$120 \mathrm{~cm}$ derinlik kademelerine göre el küreği ile (bozulmuş) ve $100 \mathrm{~cm}^{3}$ 'lük silindir ile (bozulmamış) toprak örnekleri alınmıştır. Bozulmuş toprak örneklerinde tekstür, $\mathrm{pH}$, tuzluluk, kireç, organik madde ve makro besin elementleri $(\mathrm{N}, \mathrm{P}, \mathrm{K})$ analizleri, bozulmamış toprak örneğinde taşlılık ve faydalı su miktarı (FSK) analizleri yapılmıştır.

\subsubsection{Laboratuvar çalışması}

Araziden alınarak kurutma odasına serilen ve hava kurusu durumuna getirilen toprak örnekleri, öğütülüp $2 \mathrm{~mm}$ elekten geçirilmiş, elde edilen ince topraklar $105^{\circ} \mathrm{C}$ 'de kurutulup fırın kurusu ağırlıkları bulunmuştur. Bulunan değerlerin örnek hacmine oranı ile firın kurusu ağırlıkları "g/l”" (Kantarcı, 2005) olarak bulunmuştur. Eleğin üstünde kalan taş ve çakıl miktarı hacim olarak belirlenmiş ve alındığ 1 örneğin hacmine oranlanarak (Kantarc1, 2005) bulunmuştur. Tane çapı Bouyoucos’un hidrometre yöntemiyle (Irmak, 1954; Gülçur, 1974) belirlenmiştir. Toprak reaksiyonu cam elektrotlu pHmetre ile elektriki iletkenlik (EC) saturasyon çamuru ekstraktında Schott CG 855 kondüktivitimetre aleti ile karbonat içeriği Scheibler kalsimetresi (Irmak, 1954; Gülçur, 1974) ile ölçülmüştür.

Organik karbon (Corg), Walkley-Black'in 1slak yakma yöntemi (Irmak, 1954; Gülçur, 1974) ile bulunmuştur. Bitkiler tarafından alınabilir fosfor (P) sodyum bikarbonat yöntemine göre (Olsen ve ark., 1954; Irmak, 1954; Gülçur, 1974), değiştirilebilir potasyum (K) $1 \mathrm{~N}$ amonyum asetat yöntemine (Gülçur, 1974) göre belirlenmiştir. Tarla kapasitesi (TK) 1/3 atmosfer basınç altında, solma noktası (SN) 15 atmosfer basınç altında seramik levha aleti ile (Klute, 1986) tayin edilmiştir, Faydalanılabilir su kapasitesi (FSK), tarla kapasitesi sınırındaki nem miktarından solma sınırındaki nem miktarının fark1 alınarak (Kantarc1, 2000) bulunmuştur.

Toprak örneklerinde yapılan analizler sonucu elde edilen yüzde değerler (100 g kuru madde için) her toprak derinlik kademesinde bir litre hacmindeki ince toprak miktarı ile çarpılarak birim hacimdeki değerlere çevrilmiştir. Ardından toprak derinliği ile çarpılarak her kademede bir $\mathrm{m}^{2}$ yüzeye sahip derinlik hacim değerleri elde edilmiştir. Derinlik kademelerindeki madde miktarları toplanarak bir $\mathrm{m}^{2}$ yüzeye sahip ve bir m derinlikteki toprak sütunundaki madde miktarları ( Kantarcı, 2005) elde edilmiştir.

\subsubsection{Verilerin değerlendirilmesi}

İstatistik modellemede sınıflandırma ve regresyon ağacı tekniği (SRAT) DTREG adlı bilgisayar programı kullanılarak gerçekleştirilmiştir (Sherrod, 2014). Bu programı kullanırken, modele giren bağımsız değişkenlerden bakı (baki), yamaç konumu (Yamkom), arazi yüzü şekli (arzyuz) ve anakaya değişkenleri nominal değişken olarak tanıtılmıştır (Tablo 2).

54 örnek alan içinden 9, 15 ve 32 nolu örnek alanlar çıkartılarak 51 örnek alan için istatistiksel analizler yapılmıştır. 9, 15 ve 32 nolu örnek alanlar meşe ekimi yapılmış ancak başarı elde edilememiş alanlardır. Bu alanlarda sadece toprak analizi yapılarak başarısızlığın toprak özellikleri ile ilişkisi değerlendirilmiştir.

Tablo 2. Regresyon ağaç modeline giren değişkenlere ait k1saltmalar.

Table 2. Variables and abbreviations used in the regression tree model

\begin{tabular}{lc}
\hline Değişkenler & Kısaltma \\
\hline Rakım $(\mathrm{m})$ & Rakim \\
Bak1 & Baki \\
Eğim (\%) & Egim \\
Yamaç konumu & Yamkom \\
Arazi yüzeyi şekli & Arzyuz \\
Anakaya & Anakaya \\
İklim & İklim \\
Mutlak toprak Derinliği & Horkal \\
İnce toprak miktarı $\left(\mathrm{kg} / \mathrm{m}^{3}\right)$ & İncetop \\
Profil taşl1lı̆ı $\left(\mathrm{kg} / \mathrm{m}^{3}\right)$ & Tas \\
Kum miktarı $\left(\mathrm{kg} / \mathrm{m}^{3}\right)$ & Kum \\
Toz miktarı $\left(\mathrm{kg} / \mathrm{m}^{3}\right)$ & Toz \\
Kil miktarı $\left(\mathrm{kg} / \mathrm{m}^{3}\right)$ & Kil \\
Organik karbon miktarı $\left(\mathrm{g} / \mathrm{m}^{3}\right)$ & Orgkar \\
Faydalı su miktarı $\left(\mathrm{mm} / \mathrm{m}^{3}\right)$ & Fsk \\
Tüm azot $\left(\mathrm{g} / \mathrm{m}^{3}\right)$ & $\mathrm{Nt}$ \\
Alınabilir fosfor $\left(\mathrm{g} / \mathrm{m}^{3}\right)$ & $\mathrm{P}$ \\
Değiştirilebilir potasyum $(\mathrm{g} / \mathrm{m} 3)$ & $\mathrm{K}$ \\
Q. brantii $\mathrm{L}$. ortalama dip çap & Qbdc \\
Q. brantii $\mathrm{L}$. maksimum boy & Qbmax \\
Q. brantii $\mathrm{L}$. ortalama boy & Qbortb \\
Q. cerris $\mathrm{L}$. ortalama dip çap & Qcdc \\
Q. cerris $\mathrm{L}$. maksimum boy & Qcmax \\
Q. cerris $\mathrm{L}$. ortalama boy & Qcortb \\
\hline
\end{tabular}

\section{Bulgular}

\subsection{Quercus brantii L. (İran palamut meşesi)'ye ait bulgular}

\subsubsection{Quercus brantii L. ortalama dip çap (Qbdc)}

Qbdc değişkeni için uygulanan regresyon ağac1 tekniğinin sonucu Şekil 3'te verilmiştir. Elde edi- 
len ağaç modelin eğitim seti için $=0,756$ ve test seti için $=0,509$ olarak belirlenmiştir. Ağaç modeli oluşturan değişkenler önem sırasına göre eğim (nispi önem düzeyi, \%100), bak1 $(\% 55,2)$ ve toprak rezerve kum içeriği $(\% 53,7)$ değiş̧kenleridir.

Ağaç modele göre, Qbdc değerleri, eğimin \%15'den düşük olduğu ve kum (rezerve) değeri içeriğinin $712,7 \mathrm{~kg} / \mathrm{m}^{3}$ 'den yüksek toprakların olduğu yerlerde en yüksek çıkmıştır. Ağaç model, en düşük Qbdc'nin değerleri için eğimin \%15'in üstünde ve 1 (güney), 3 (doğu), 6 (kuzeybatı) ve 7 (kuzey) nolu bakıların olduğu yerleri ifade etmiştir.

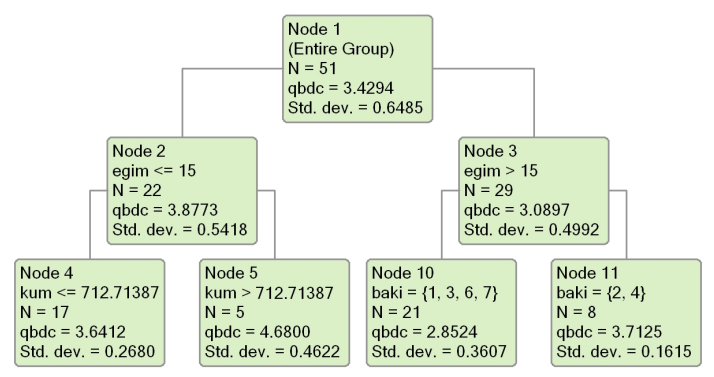

Şekil 3. Qbdc regresyon ağacı modeli.

Figure 3. Regression tree model for Qbdc

\subsubsection{Quercus brantii L. maksimum boy (Qbmax)}

Qbmax değişkeninin ağaç model sonuçları beklendiğinden daha düşük çıkmıştır $(0,41672$ ve test seti için $=0,13069)$. Zira örnek alanlarda türler aynı yaşlı olduğu için, maksimum boy türe ait verimliliği en iyi şekilde yansıtan değişkendir. Model tek bir değişken ince toprak miktarı (\%100) ile yapılandırılmıştır. Modele göre ince toprak miktarının $1.412,2 \mathrm{~kg} / \mathrm{m}^{3}$ 'den yüksek olduğu yerlerde Qbmax değerleri genelde daha yüksek olmaktadır (Şekil 4).

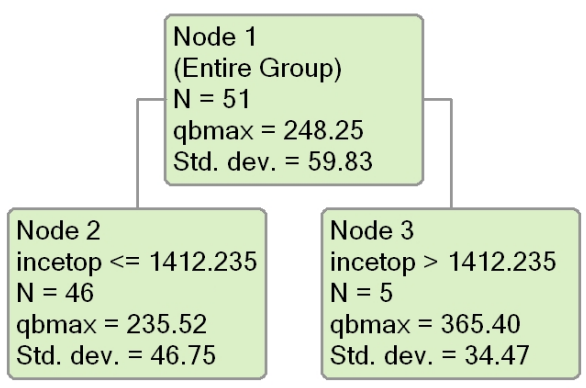

Şekil 4. Qbmax regresyon ağacı modeli Figure 4. Regression tree model for Qbmax

\subsubsection{Quercus brantii L. ortalama boy (Qbortb)}

Qbortb, ağaç modelinin eğitim setine ait $=0,72023$ olarak belirlenmiştir. Test seti sonuçları ise
$(0,26268)$ bulunmuştur. Ağaç modelin oluşumunda en etkili değişkenler sırasıyla toprak rezerve kum içeriği $(\% 100)$, eğim $(\% 38,8)$, bakı $(\% 12,7)$, anakaya $(\% 5,1)$ ve rakım $(\% 3,1)$ olmuştur.

Ağaç modele göre (Şekil 5), en yüksek Qbortb değerleri, topraktaki kum içeriğinin (rezerve) 776,6 $\mathrm{kg} / \mathrm{m}^{3}$, ten fazla olduğu yerlerdir. Model, en düşük Qbortb'un değerleri için toprağın kum içeriğinin (rezerve) $776,6 \mathrm{~kg} / \mathrm{m}^{3}$ 'den az olduğu, eğimin \%15'den yüksek olduğu, 3 (doğu), 5 (bat1), 6 (kuzeybatı) ve 7 (kuzey) nolu bakıların yer aldığı, 1.495 m'den yüksek yerleri ifade etmektedir.

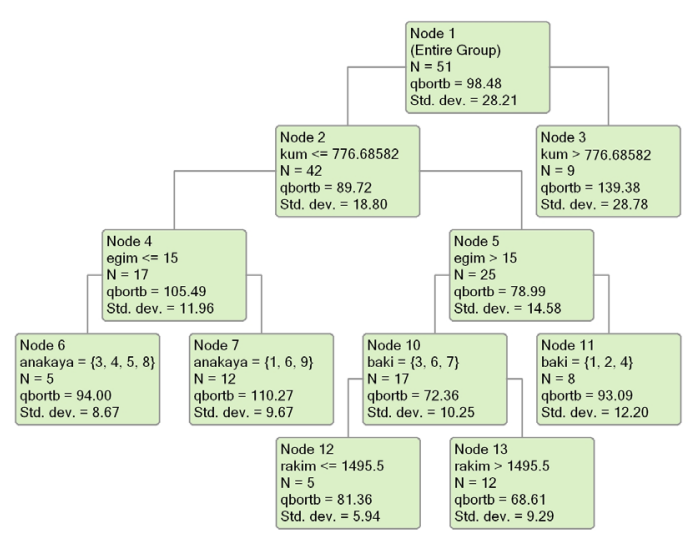

Şekil 5. Qbortb regresyon ağacı modeli Figure 5. Regression tree model for Qbortb

\subsection{Quercus cerris L. (saçlı meşe)'ye ait bulgular 3.2.1. Quercus cerris L. ortalama dip çap (Qcdc)}

Qcdc değişkeni için uygulanan regresyon ağac1 tekniğinin sonucu Şekil 6 'da verilmiştir. Elde edilen ağaç modelin eğitim seti için $=0,47117$ ve test seti için $=0,04307$ olarak belirlenmiştir. Ağaç modeli oluşturan değişkenler anakaya (\%100) ve rakımdir $(\% 24,7)$.

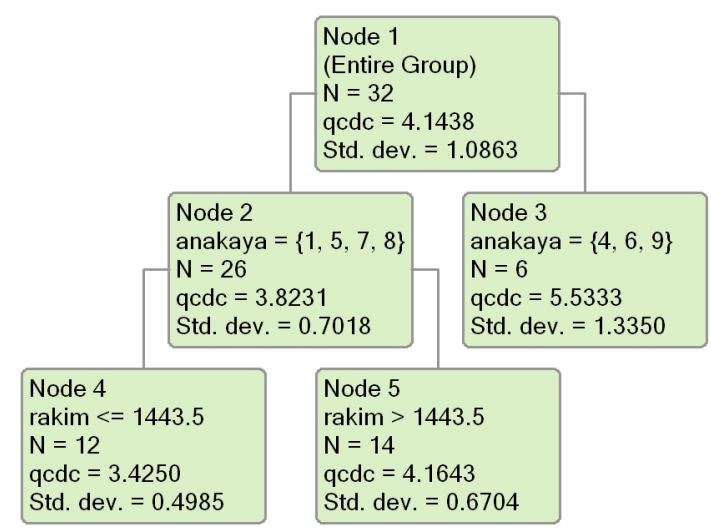

Şekil 6. Qcdc regresyon ağacı modeli Figure 6. Regression tree model for Qcdc 
Ağaç modele göre, Qcdc değerleri, 4 (granit-diyorit),6 (serpantin-diyabaz) ve 9 (serpantin-bazalt) nolu anakayaların olduğu yerlerde en yüksek çıkmıştır. Ağaç modele göre en düşük Qcdc'nin değerleri, rakımın 1.443 m'den alçak ve 1 (granit), 5 (serpantin), 7 (gabro), 8 (gabro-serpantin), nolu anakayanın olduğu yerlerdir.

\subsubsection{Quercus cerris L. maksimum boy (Qcmax)}

Qcmax değişkeni için uygulanan regresyon ağac1 tekniğinin sonucu şekil 7'de verilmiştir. Elde edilen ağaç modelin eğitim seti için $=0,67547$ ve test seti için $=0,14126$ olarak belirlenmiştir. Ağaç modeli oluşturan değişkenler önem sırasına göre mutlak toprak derinliği $(\% 100)$, rakım $(\% 15,2)$ ve toprak rezerve kil içeriği $(\% 5,5)$ 'dir.

Ağaç modele göre, Qcmax değerleri mutlak toprak derinliğinin $45 \mathrm{~cm}$ 'den fazla olduğu yerlerde en yüksek çıkmıştır. Ağaç model, en düşük Qcmax’ın değerleri için mutlak toprak derinliğinin $45 \mathrm{~cm}$ ve daha az, rakımın 1.479 m' den alçak olduğu yerler olarak ifade etmiştir.

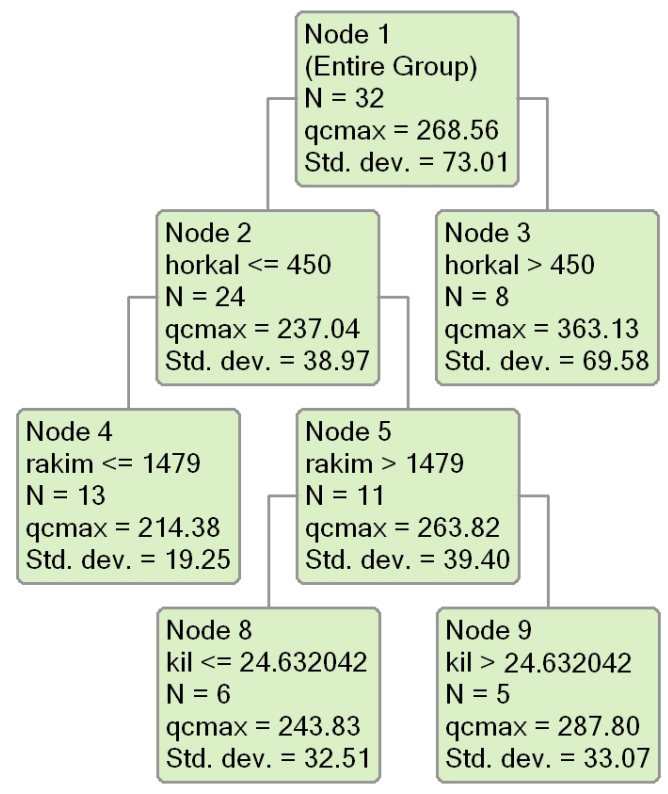

Şekil 7. Qcmax regresyon ağacı modeli Figure 7. Regression tree model for Qcmax

\subsubsection{Quercus cerris L. ortalama boy (Qcortb)}

Qcortb değişkeni için uygulanan regresyon ağac1 tekniğinin sonucu Şekil 8'de verilmiştir. Elde edilen ağaç modelin eğitim seti için $=0,49697$ ve test seti için $=0,00000$ olarak belirlenmiştir. Ağaç modeli oluşturan değişkenler önem sırasına göre, toprak rezerve kil içeriği $(\% 100)$, rakım $(\% 35,5)$ ve fsk $(\% 21)$ değişkenleridir.

Ağaç modele göre Qcortb değerleri topraktaki kil içeriğinin (toprak rezerve kil içeriği) $60,4 \mathrm{~kg} / \mathrm{m}^{3}$, den yüksek ve rakımın 1.509 m'den yüksek olduğu yerlerde en yüksek çıkmıştır. Ağaç model göre en düşük Qcortb'nin değerleri, toprak kil içeriğinin $60,4 \mathrm{~kg} / \mathrm{m}^{3}$ 'den az ve toprakta faydalanilabilir su miktarının $18,9 \mathrm{~mm} / \mathrm{m}^{36}$ ten az olduğu yerlerdir.

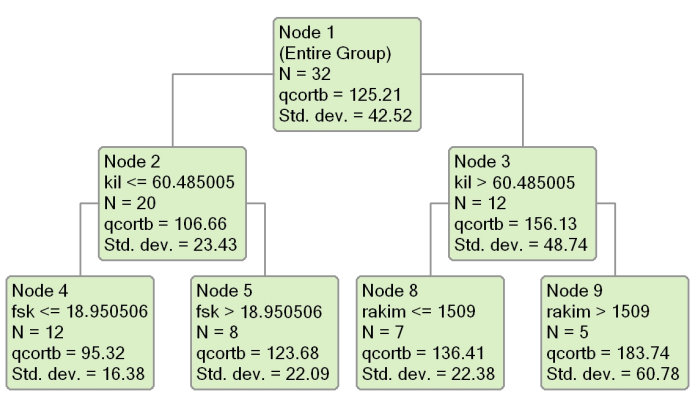

Şekil 8. Qcortb regresyon ağaç modeli Figure 8. Regression tree model for Qcortb

\subsection{Meşe ekimleri başarısız olunmuş örnek alanlara ait bulgular}

Meşe palamudu ekimi yapıldığı halde ağaçlandırma tesisinde başarısız olunan örnek alanlarında $(9$, 15 ve 32) alınan toprak örneklerinin analizinde; üç örnek alanının toprak tekstürü kumlu balçık, $\mathrm{pH}$ değerleri 6,4-6,9 değerleri arasında, tuzsuz ve az kireçlidir. Organik madde miktarı bakımından 9 nolu örnek alanın çok fakir, 15 nolu örnek alanı fakir, 32 nolu örnek alanı ise orta derecede bulunmuştur. N, P, K bakımından sırasıyla çok az, çok yüksek ve düşük olan ortak değerler, 32 nolu örnek alanındaki azotun yeterli oluşu $(\% 0,15)$ bakımından farklılık göstermektedir. 9, 15 ve 32 nolu örnek alanlarının faydalı su miktarları birbirine yakındır $(\% 7,2-\% 8,9-\% 8,7)$.

Başarılı örnek alanların toprak analiz sonuçları ile başarısız örnek alanlara ait toprak analiz sonuçları karşılaştırıldığında toprak özelliklerinin birbirine yakın olduğu görülmektedir. Bu nedenle bu üç alanda meşe palamudu ekimlerinde görülen ağaçlandırma tesisindeki başarısızlığın mevcut toprak özelliklerinden kaynaklanmadığını söylemek mümkündür.

\section{Tartışma}

Çalışma sonuçlarına göre, yetişme ortamı özelliklerinden eğim, bak1, rakım, anakaya türü ve toprak özelliklerinin Quercus brantii L. (İran palamut meşesi) ve $Q$. cerris (saçlı meşe) türlerinin 
çap artımı ve boy büyümesi üzerinde etkili olduğu görülmüştür. Değişik meşe türleri için yapılan çalışmalarda benzer sonuçlara ulaşılmıştır. Auchmoody ve Clay-Smith (1979), sayısız çalışmanın sonucunda belirli bir alandaki orman verimliliğinin, arazinin çeşitli toprak ve topografik özellikleri ile ilişkili olduğunu belirtmişlerdir. Meşe türü için bu çalışmalardan altı tanesi ABD’nin Batı Virginia, Batı Maryland, Ohio ve Pennsylvania bölgelerinde tamamlanmıştır (Gaiser, 1951; Trimble-Jr ve Weitzman, 1956; Yawney, 1964; Carmean, 1965; Yawney ve Trimble-Jr, 1968; Bowersox ve Ward, 1972). Buna ek olarak, birçok başka yetişme ortamı çalışması, çok sayıda türün (meşe dahil) yetişme ortamı veriminin tahmin edilmesi için toprak derinliği, tekstürü ve drenajının yanı sıra, bakının, yamaç konumunun ve yamaç dikliğinin önemini doğrulamıştır (Carmean, 1970; Carmean, 1973 ve Carmean, 1975).

Çalışma sonuçları, en yüksek Qcdc, Qcmax ve Qcortb değerlerini sırasıyla $1.443 \mathrm{~m}, 1.479 \mathrm{~m}$, 1.509 m'den yüksek rakımlı yerlerde olduğunu göstermektedir. Oysa Şentürk ve ark. (2014), göre; o yörede yükselti değişkeninin 1.233 m’den düşük yerlerin saçlı meşe türünün potansiyel dağılımında etkili olan tek faktör olduğu sonucuna varmıştır. Aynı türe ait benzer bir sonuçta ise türün özellikle $850 \mathrm{~m}$ yükseltiden daha alçak yerlerde, daha 1lıman ve kurak ortamlarda ekolojik olarak adaptasyonunun yüksek olduğu bildirilmiştir (Gülsoy ve ark., 2016). Aslında saçlı meşe bulunduğu ortamların ekstrem koşullarına diğer meşe türlerine göre daha iyi adaptasyon sağlaması (de Rigo ve ark., 2016), yarı kurak ve yarı nemli iklimin hâkim olduğu örnek alanlarımızda zor ekolojik şartların hüküm sürdüğü yüksek rakımlardaki boy büyümesinin daha iyi olmasını açıklamaktadır. Yaltırık’ın (1984), saçl1 meşenin denizden yüksekliğin 1.500-1.900 m'ye kadar diğer meşelerle (Quercus frainetto, Q. pubescens, $Q$. infectoria, $Q$. petraea, $Q$. libani) birlikte, yaprakli ormanlarda (Fagus spp, Carpinus spp, Castanea spp), Pinus nigra, P. brutia ve $P$. pinea gibi iğne yapraklı ormanlarda karışıklığa girdiği veya saf meşcereler kurduğu ifadeleri ile proje bulgularımızla paralellik arz etmektedir. Ayrıca, Özkan ve ark. (2006), saçlı meşe türünde 200-600 m rakımlı yükseltiler için negatif ilişki tespit ederek, saçlı meşe türünün 600 m rakımdan daha yüksek rakımlarda kullanılmasını önermiştir.

Çalışma sonuçlarımıza göre, en düşük Qbortb değerleri rakımın 1.495 m'den yüksek olduğu yerlerdir. Yaltırık (1984), türün ülkemizde Doğu ve Güneydoğu Anadolu Bölgelerinde doğal olarak bulunduğunu ve 350-1.700 m yükseltileri arasında saf meşcereler kurduğu gibi diğer meşe türleri ( $Q u$ - ercus infectoria subsp boissieri, Q. libani, Q. cerris), kızılçam (Pinus brutia), Pistacia eurycarpa, Pyrus ssp. ile karışıklığa girdiğini ifade etmiştir. Talebi ve ark. (2009), türün 1.050-2.550 m yükseltileri arasında doğal yayılış yaptığını ifade etmiştir. Aynı ülkede yapılan bir başka çalışmada ise İran palamut meşesinin 1.800-2.000 m yükseltiler arasında, güneybatı yamaçlarda ve 1şı isteği yüksek olan bir tür olduğu belirtilmiştir (Mahmoud ve ark., 2006). Örnek alanlarımızın tamamımda (1.348-1.790 m) yayılış gösteren İran palamut meşesinin araştırmamızdaki en düşük ortalama boy değerlerinin $1.495 \mathrm{~m}$ rakımdan sonra görülmesi yükseltiye bağlı sıcaklıktaki düşme ve vejetasyon gün sayısındaki azalma ile açıklanabilir. Sevim (1960), meşelerin yetişme ortamı isteklerini açıklarken sıcaklık isteklerinin yüksek ve büyümelerinin nispeten yavaş olduğunu ifade etmiştir. En düşük ortalama boy değerlerinin ölçüldüğü örnek alanların $(10,18,19,36,40,41$ ve 47) ortak özellikleri ise rakımlarının 1.495 m yüksek, bakılarının gölgeli ve eğimlerinin \%22'den fazla olmasıdır. Bu örnek alanların rakımlarının yüksekliği ile birlikte gölgeli bakılarda yer alması, yüksekliğe bağlı s1caklıktaki düşüş miktarını daha da arttırdığı, aynı zamanda 1şık isteği fazla olan meşenin iyi büyüme için yeterli 1 şık alamadığı ve buna bağlı ortalama boy büyümelerinin yavaşladığı düşünülmektedir.

Çalışma sonuçları, en yüksek Qcdc değerlerinin eğimin \%15'ten düşük olduğu yerlerde ölçüldüğünü göstermektedir. Düşük eğimlerde daha derin toprak, az miktardaki iskelet nedeni ile yüksek eğimlere göre daha iyi besin ve su ekonomisine sahip olması ölçülen farklılıkların nedeni olabilir. Boy artışının veya yetişme ortamı endeksinin genellikle toprağın besin ve su sağlama kabiliyeti bakımından daha iyi olduğu yerler olan düşük eğimlerde daha büyük olması olağandır (Çepel, 1995; White, 1958; Fralish, 1994; Johnson ve ark., 2009). Aynı şekilde, güney Portekiz'de mantar meşesi (Quercus suber L.) türünde büyüme ile toprak, eğim ve drenaj ilişkisinin araştırıldığı proje bulgularına göre, dik eğimler (\%16'dan fazla) göğüs çapın1, ağaç sıklığını (yoğunluğunu) ve mantar üretimini azaltmaktadır (Costa ve ark., 2008). Bu sonuçlar, genel olarak orta tekstür (kumlu balçık) toprakların yer aldığı örnek alanlarımızda artan eğimle boy büyümesinde görülen azalmalarla paralellik arz etmektedir.

Türkiye'de genel olarak güneye bakan yamaçlar toprak derinliği (gece-gündüz sıcaklıkları arsında büyük fark, toprakta parçalanma ve ufalanma olaylarının yaşanması ile erozyonun daha fazla görülmesi nedeni ile), besin ve su ekonomisi bakımından kuzeye bakan yamaçlara göre olumsuz 
bir durum göstermektedir. Ancak, meşe türlerinin genel olarak 1şığ1 ve sıcaklığ1 (Sevim, 1960) tercih ettiği bilinmektedir. Nitekim Russell (1971), yüksek dağ meşe ekimlerini araştırdığı projesinde, meşelerin en iyi büyüme için bol güneş 1şığına ihtiyaç duyduklarını ve bu nedenle rakip bitki örtüsü kontrol edilmesi gerektiği belirterek, buna rağmen ilk yıllardaki boy büyümesinin hayal kırıklığı yaratabileceğini ifade etmiştir. Keza, Hannah (1968), ABD'nin güney Indiana'daki ak meşe (Quercus alba L.) yetişme ortamı kalitesi, kuzey yönündeki (KB, K, KD, D) yamaçlarda, daha güney (GD, $\mathrm{G}, \mathrm{GB}, \mathrm{B})$ yönlerine göre daha iyi olduğunu, ancak kara meşe (Quercus velutina L.) için yetişme ortamı ilişkilerinde bakının önemli bir faktör olmad1ğını belirtmiştir.

Bakının etkisi bakımından özetlediğimiz farklı sonuçların mevcudiyeti bu çalışmamızda da tespit edilmiştir. En yüksek Qbdc değerleri, güney, doğu, kuzeybatı ve kuzey bakılarda, en düşük Qbortb değerleri ise doğu, bat1, kuzeybat1, kuzey bakılı yamaçlarda ölçülmüştür. Aslında, yamaç yönü aynı zamanda güneş radyasyonu ve mikroklima üzerindeki etkisinden dolayı orman verimliliğini de etkiler, ancak tek başına bakı arazideki verimlilik değişkenliğini tamamen açıklayamaz (Trimble-Jr ve Weitzman, 1956; Rosenberg ve ark., 1983; Fekedulegn ve ark., 2003). Proje bulgularımız, bakının meşe türlerinin boy ve dip çap artımlarını, eğimin $\% 15$ 'den az ve rakımın 1.495 m'den düşük olduğu yerlerde birlikte etkilediğini göstermektedir.

Çalışma sonuçlarımıza göre en yüksek Qcdc değerleri, granit-diyorit, serpantin-diyabaz ve serpantin-bazalt anakayalarının yer aldığı örnekleme alanlarında ölçülmüştür. En yüksek Qbort değerleri granit, serpantin-diyabaz, serpantin-bazalt, en düşük değerler ise diyorit, granit-diyorit, serpantin, gabro-serpantin anakayalarının bulunduğu örnek alanlarımızda ölçülmüştür.

Çalışma sonuçlarına göre Qbdc ve Qbort değerlerini birim $\mathrm{m}^{3}$ topraktaki kum içeriği (sırasıyla 712 ve $776,6 \mathrm{~kg} / \mathrm{m}^{3}$ ) pozitif yönde etkilemiştir. Aslında, toprak bünyesinde kum miktarının artması fiziksel özellikler bakımından olumlu katkı sağlasa da toprağın verimliliğini azaltır (Karaöz, 2015). Keza, Saraçoğlu ve Kantarcı (1999), saplı meşe baltalıklarında kum faktörünün sürgün boyu üzerinde etkisini azalan yönde saptamışlardır. Örnekleme alanlarımızın yarı kurak ve yarı nemli iklim etkisinde olduğu da dikkate alındığında toprak nemine olumsuz etki yapacak kum miktarının artmasının, çap ve büyüme artımında negatif etki yapması gerekirdi. Ancak, dip çap ve boy büyümesinin birim hacimdeki kum miktarı ile arttığı örnekleme alan$\operatorname{lar} 1(1,2,13,29,35,42,43,51$ ve 53 nolu) incelen- diğinde, bu örnekleme alanlarının ortak yönlerinin toprak mutlak derinliğinin 90-120 cm arasında olduğu ve 3-4 derinlik kademesinden toprak örneği alındığ 1 , bu nedenle birim hacimdeki kum miktarının arttığ1 görülmüştür.

Ayrıca, bu örnekleme alanlarımızda birim hacimdeki toprak miktarının diğer örnekleme alanlarına göre fazla olması nedeni ile besin (N, P, K) ve FSK miktarları da yüksektir. Keza, Karatepe ve ark. (2005), Toros sedirinin en iyi büyümesini ve çap artımını pedondaki toprak miktarının en çok olduğu alüvyon topraklarında yaptığını tespit etmişlerdir. Benzer bir sonuç Polat ve ark. (2014), tarafindan sedir ve karaçam ağaçlandırmalarının boy gelişimi ile bazı yetişme ortamı özellikleri arasındaki ilişkinin araştırıldığı projede elde edilmiş ve toprak rezerve kum içeriği ile karaçamın üst boyu arasında pozitif ilişki tespit edilmiştir.

Toprağın birim $\mathrm{m}^{3}$ rezerve içeriğinde ince toprak miktarının artması (1412,2 kg/m³'ten fazla), Qbmax'nin değerlerini arttırmıştır. Örnekleme alanlarından alınan toprak örneklerinin analiz sonuçlarına göre genel olarak orta tekstürlü (kumlu balçık) topraklar hakimdir. Bu toprak tekstüründe ince toprak miktarındaki artış, saçak kök sistemini daha da yaygınlaştırarak besin ve nem ekonomisini olumlu etkilediği dolayısıyla boy büyümesinde artışa neden olduğu düşünülmektedir. Benzer şekilde, ülkemizde çeşitli orman ağaçlarının boy gelişimi ile toprak özelliklerinin incelendiği birçok çalışmada ince toprak miktarı ile boy büyümesi arasında istatistiksel açıdan anlamlı ilişkiler saptanmıştır (Çepel ve Dündar, 1980; Güner, 2008; Polat ve ark., 2014).

Meşe palamudu ekimi yapılan örnekleme alanlarının tümünde fizyolojik derinlik mevcut olup, mutlak toprak derinliği (solum) 30-120 cm arasında değişmektedir. Mutlak toprak derinliğinin $45 \mathrm{~cm}$ 'den fazla olduğu topraklarda Qcmax'ye ait değerler artmıştır. Mutlak toprak derinliğinin $45 \mathrm{~cm}$ 'den fazla olduğu yerlerde ağaç kökleri daha fazla kullanım alanı bulacak, tersine bir durumda ise fizyolojik derinlik olsa bile birim alandaki taş hacminin artması köklerin kullanım alanını küçültecektir. Daha büyük toprak hacminden faydalanmak besin ve su ekonomisi bakımdan avantaj sağlayacağından boy büyümesine olumlu katkı sağlayacaktır.

Carmean (1961), ABD’nin güneybatı Ohio'daki kara meşenin (Quercus velutina L.) toprak ve yetişme ortamı endeksi arasındaki ilişkiyi incelediği proje bulgularına göre, yetişme ortamı verimliliğinin tahmin edilmesinde toprak derinliği önemli bir rol oynadığını tespit etmiştir. Benzer şekilde Einspahr ve Comb (1951), toprak derinliğinin art- 
masıyla yetişme ortanı indeksinin arttığını ifade etmişlerdir. Ancak, Yawney ve Trimble-Jr (1968), meşelerin toprak ve yetişme ortamı ilişkilerini araştırdıkları proje sonuçlarına göre, toprak derinliğinin 180 cm'ye kadar ulaşması ile meşcere üst boyu arasında zayıf ancak anlamlı bir ilişki bulunmuştur.

Qcortb'ye ait değerler toprak rezerve kil içeriğinin $60,4 \mathrm{~kg} / \mathrm{m}^{3}$ 'den fazla ve fsk miktarının $18,9 \mathrm{~mm} /$ $\mathrm{m}^{3}$ 'ten yüksek olduğu yerlerde artmıştır. Birim $\mathrm{m}^{3}$ toprak hacminde kil miktarının artması hem besin maddelerinin hem de suyun daha fazla tutulmasina neden olacağından boy büyümesine olumlu katk1 yapması beklenen bir sonuçtur. Kuzey Fransa'da aynı yaşlı yüksek dağ orman meşcerelerinde sapsız meşenin (Quercus petraea Liebl.) yetişme ortamı (bonitet) endeksinin iklim, topografya ve toprakla ilişkisinin araştırıldığ 1 bir projede, toprak su tutma kapasitesinin, yamaç konumu ve bazı besin maddeleri ile birlikte yetişme ortamı verimliğini pozitif etkilediği tespit edilmiştir (Berges ve ark., 2005).

Sohar ve ark. (2013), çeşitli ülkelerde meşe türlerinin iklimden etkilenmesini; Bronisz ve ark. (2012), Cedro’ya (2007), atfen Polonya'daki meşe türlerindeki boy büyümesi yaz mevsimindeki yağışların etkisinde kalırken, yüksek sıcaklığın olumsuz etki yarattığını belirtmişlerdir. Meşe türlerindeki zayıf boy büyümesi, esas olarak Çek Cumhuriyeti’nde (Doležal ve ark., 2010) ve Almanya'da yaz mevsiminde su açığına atfedilmektedir (Friedrichs ve ark., 2009; Scharn-Weber ve ark., 2011; Zang ve ark., 2012). İngiliz adalarındaki (kuzey İskoçya d1şındaki Britanya adaları olan İrlanda, İskoçya, İngiltere ve Galler'de eşit şekilde dağıtılmış 16 örnek alanda) meşe çalışmalarında ise yaz mevsimi boyunca ve büyüme mevsiminde yüksek yağışların büyümeyi desteklediğini göstermiştir (Pilcher ve Gray, 1982; Bridge ve ark., 1996).

İklimin boy büyümesi üzerinde etkisini açıklayan birçok araştırmaya rağmen; çalışmamızda iklimin etkisi elde edilememiştir. Bunun nedeninin iki ayrı iklim bölgemizin Thornthwaite iklim sınıflandırmasına göre birbirine yakın kuraklık indis değerlerine sahip olması (yarı kurak iklim: 12,5, yarı nemli iklim: 13,3) ve her iki iklim bölgesinde aynı aylarda (vejetasyon döneminde) 5 aylık su açığı bulunması olduğunu düşünmekteyiz.

Büyüme döneminde yağışın ve toprakta bulunan nem miktarının meşe türlerinin boy büyümesini etkilediği yönünde yayınlanmış görüşler bulunmaktadır. Örneğin Berges ve Balandier (2010), bazı yazarlara (Rambal, 1984; Bre' da ve Granier, 1996; Otieno ve ark., 2006) atfen bildirdiğine göre, son yıllarda ılıman ve Akdeniz ekosistemlerinde farklı ağaç türleri üzerine yazılmış bazı makaleler, kuraklık veya su açığı dönemlerinde derin toprak katmanlarında (1-2 m arası) su alımının ağaç büyümesine katkıda bulunmadığını, sadece ağacın hayatta kalmasına katkıda bulunduğunu vurgulamıştır. Ayrıca, Urbieta ve ark. (2011) yetişkin ağaçlarının dağılımı temel olarak geçmiş (iklim, yönetim vb.) koşullara bir yanıtın yansıması olsa da, türlerin genç yaşam evresinde (fideler) mevcut çevresel koşullara tepki verdiğini belirtmişlerdir. Örnekleme alanları palamut ekimi yoluyla ağaçlandırılmış meşe ormanı sahalarından alınmıştır ve bu nedenle büyümede iklim etkisinden çok çevresel koşulların etkisi ön plana çıkmış olabilir.

Yamaç konumu ve arazi yüzeyi şekli faktörleri, ağaç model regresyon analizinde etkisi bulunamayan faktörlerdendir. Yamaç konumu, yamaç uzunluklarının fazla olmaması nedeni ile üst, orta ve alt yamaç olarak dağıtılmıştır. Üst yamaç ve diş bükey yamaçlarda alt yamaç ve iç bükey yamaçlara göre daha hızlı yüzeysel akış dolayısıyla da daha az su depolaması beklenir. Ancak, yapılan riperle derin toprak işlemesi üst yamaç ve diş bükey yamaçlarda yüzeysel akışı yavaşlatmak suretiyle yamaç konumu ve arazi yüzey şekilleri arasındaki su depolama farkını azalttığı, bu nedenle dip çap artımlarında ve boy büyümesinde bu faktörlerin etkisinin görülmediği düşünülmektedir. Oysa Kabrick ve ark. (2004), hem ak meşe (Quercus alba L.), hem de kara meşe (Quercus velutina Lam.) türü için en yüksek yetişme ortamı bonitetlerinin toprakların daha derin olduğu ve üst yamaçlardan gelen sedimentin biriktiği iç bükey orta yamaçlar olduğunu belirtmişlerdir. Keza, Hannah (1968), meşelerin toprak ve topografya ilişkisini araştırdığı proje bulgularına göre kuzeye bakan alt yamaçlarda nem ve sıcaklığın ağaç büyümesi için daha iyi olduğunu ifade etmiştir. Ancak Shostak ve ark. (2004), ABD'nin kuzey Alabama'da yüksek dağ ormanlarındaki yapraklı ağaçlarda kesim sonrası gelen meşe gençliğinin üst yamaç pozisyonunda en bol ve alt yamaç pozisyonunda en düşük olduğunu tespit etmişlerdir.

Meşe palamut ekimi yapılan ancak ağaçlandırma tesisinde başarısız olunan üç adet örnek alanda (9, 15 ve 32 nolu) alınan toprak örneklerinin analiz sonuçları ile başarılı olunan örnek alanların toprak analiz sonuçlarının karşılaştırılması sonucu toprak özellikleri bakımından önemli farklılıklar bulunmadığ1 tespit edilmiştir. Başarılı örnek alanlar ile iç içe olan bu alanlarda, domuz, fare ve kargalar ekilen palamutları yemek suretiyle zarar vermiştir. $\mathrm{Bu}$ zararlara ait gözlemler mevcuttur (toprak altında fare yolları, domuz ve karga izleri v.b).

51 adet örnek alanda saçlı meşe ve İran palamut meşe fidanları 18 yılda sırasıyla $84 \mathrm{~mm}$ ve $55 \mathrm{~mm}$ 
çap artımı (yıllık sırasıyla 4,6 mm ve $3 \mathrm{~mm}), 465$ $\mathrm{cm}$ ve $432 \mathrm{~cm}$ boy büyümesi (yıllık sırasıyla 25,8 $\mathrm{cm}$ ve $24 \mathrm{~cm}$ ) gerçekleştirmiştir. Russell (1971), ABD'nin merkez Tennessee'deki kuzey kızıl meşe (Quercus rubra L.) türünün, ekimden sonra genellikle 5 ila 10 yıl arasında yılda ortalama $30,4 \mathrm{~cm}$ büyüdüğünü belirtmiştir. Elâzığ ili ve çevresinde yapılan toprak muhafaza amaçlı ağaçlandırmaların $1.100 \mathrm{~m}$ rakımdan yüksek yerlerde yapıldığ göz önüne alındığında tür seçiminde yavaş büyümelerine rağmen ağaçlandırma tesis ederken meşe palamudu ekimlerinin ön planda tutulması gerekmektedir. Çünkü yapılan toprak muhafaza ağaçlandırmalarının asli amacı toprak muhafazasıdır, üretim tali amaçtır. Bu nedenle; ağaçlandırma tesislerinde ağaç türünü seçerken yavaş büyüme meşe türünün tercih edilmeme nedeni olmamalıdır.

Son zamanlarda, meşe türleri ile beraber diğer yapraklı ağaç türlerine verilen önem artmaktadır. Hatta birçok ülkede ibreli türler kaldırılarak yapraklı türler dikilmekte veya ibreli türlere yapraklılar karıştırılmaktadır (Pausas ve ark., 2004; Eilman ve ark., 2009; Urbieta ve ark., 2011). Çünkü Avrupa ormanlarının iklim değişikliğine uyumundaki büyük potansiyel, nispeten yüksek kuraklık toleransları nedeniyle meşe türlerine bağlanmaktadır (Peñuelas ve Boada, 2003; Weber ve ark., 2007).

Ayrıca orta Avrupa ormanlarındaki biyolojik çeşitliliğin korunması bağlamında, meşe türleri ( $Q u$ ercus spp), mevcut tüm ağaç türlerinin en yüksek ilişkili çeşitliliğine sahip oldukları için son derece önemlidir (Rohner, 2012). Meşe varlığının, böceklerden (Ranius ve Jansson, 2000) ve kuşlardan (Caprio ve ark., 2009) mantarlara (Bernicchia ve ark., 2008) ve likenlere (Frei, 2003), kadar geniş bir yelpazedeki organizmaların çeşitliliği ile ilişkili olduğu gösterilmiştir. Ek olarak, meşe ormanlarındaki alt tabaka ve bitki katmanı tipik olarak oldukça zengin türlerdir (Barbier ve ark., 2008). Son derece yüksek ilişkili biyolojik çeşitliliklerine göre, meşe türleri şemsiye ağacı olarak görülmektedir (Wilcox, 1984; Ehrlich ve Murphy, 1987). Böylece, birçok Orta Avrupa ormanında koruma çabalarının ana odağı haline gelmiştir (Bonfils ve ark., 2005).

\section{Sonuç ve Öneriler}

Elâzı̆̆ ve çevresinde, ekimi yapılan Quercus cerris L. (saçlı meşe) ve Quercus brantii L. (İran palamut meşesi) türlerinin $1.348 \mathrm{~m}$ ile $1.830 \mathrm{~m}$ yükseltiler arasında doğal yayılışlarına uygun şekilde sağlıklı olarak yetişebildikleri görülmüştür. Ancak İran palamut meşesinin $1.500 \mathrm{~m}$ yükseltiden sonra yavaş büyüdüğü, saçlı meşenin ise en iyi büyümelerini bu yükseltiden sonra yaptığ 1 tespit edilmiştir. $\mathrm{Bu}$ yörede yapılacak toprak muhafaza ağaçlandırma çalışmalarında iki türün kullanılması durumunda İran palamut meşesinin alçak yükseltilerde $(<$ $1.500 \mathrm{~m})$, saçlı meşenin ise yüksek rakımlarda (> $1.500 \mathrm{~m}$ ) kullanılması boy büyümesi bakımından avantaj sağlayacaktır.

Ekimi yapılan her iki meşe türü de \%15 eğimden düşük yerlerde iyi gelişim göstermişlerdir. Düşük eğimlerde daha derin toprak bulunması, toprağın besin ve su yönünden yüksek eğimlere göre daha avantajlı olması genel olarak bu türlere avantaj sağlamaktadır. İran palamut meşesinin boy büyümesi bakımından en düşük değerleri $1.500 \mathrm{~m}$ rakımdan yüksek, \%22 eğimden fazla ve gölgeli yerlerde ölçülmüştür. Uygulayıcılar, bu şartları taşıyan yerlerde düşük eğimlere göre İran palamut meşesi ekimlerinde daha yavaş büyümeye hazırlıklı olmalidirlar.

Meşe ekimlerinin yapıldı ̆̆ 1 alanlarda boy büyümesi bakımından granit anakaya üzerinde daha iyi gelişimlerin olduğu, serpantin anakaya üzerinde ise zayıf gelişimlerin olduğu görülmüştür. Etüd proje hazırlayıcıların ve uygulayıcıların meşe ekimi yapılacak alanların tercihinde granit anakayanın bulunduğu yerleri tercih etmeleri büyüme yönünden avantaj sağlayacaktır.

Örnekleme alanlarımızın tümünde fizyolojik toprak derinliği mevcut olup, meşe ekimleri büyümelerine devam etmektedir. Ancak saçlı meşe ağaçlar1 en iyi büyümelerini mutlak toprak derinliğinin $45 \mathrm{~cm}$ 'den fazla olduğu yerlerde yapmıştır. Mutlak toprak derinliğinin $45 \mathrm{~cm}$ 'den fazla olduğu yerlerde birim $\mathrm{m}^{3}$ toprak hacmindeki besin madde ve fsk miktarı da artış göstermiştir. Saçlı meşenin fizyolojik derinlik mevcut bulunsa da mutlak toprak derinliğinin $45 \mathrm{~cm}$ 'den fazla olmasını da tercih ettiği görülmektedir. Ağaçlandırma proje hazırlayıcı ve uygulamacılarının saçlı meşe ekim alanlarını seçerken, fizyolojik derinlikle birlikte mutlak toprak derinliğinin $45 \mathrm{~cm}$ 'den fazla olmasına dikkat etmeleri boy büyümesi bakımından daha iyi sonuç almalarını sağlayacaktır.

Meşe palamudu ekimi yapılmış 51 adet örnek alanda saçlı meşesi ve İran palamut meşesi türleri 18 yılda sırasıyla $84 \mathrm{~mm}$ ve $55 \mathrm{~mm}$ çap artımı (yıllık olarak sirasiyla $4,6 \mathrm{~mm}$ ve $3 \mathrm{~mm}), 465 \mathrm{~cm}$ ve 432 $\mathrm{cm}$ boy büyümesi (yıllık olarak sırasıyla $25,8 \mathrm{~cm}$ ve $24 \mathrm{~cm}$ ) gerçekleştirmiştir. Yıllık dip çap artımı ve boy büyümesi bakımından saçlı meşe, İran palamut meşesinin biraz önünde görülmektedir.

Ağaçlandırma projesi hazırlayıcı ve uygulamacılarının iki tür arasında tercih yapmaları durumunda saçlı meşeyi tercih etmelerinin dip çap artımı ve boy büyümesi bakımından iyi sonuçlar elde etme- 
lerine neden olacaktır. Ancak; toprağın yerinde tutulması asli amacı ile yapılan toprak muhafaza çalışmalarında diğer türlere nazaran meşe türlerinin daha fazla tercih edilmesinin yararlı olacağ düşünülmektedir. Bu tercihin sadece toprak muhafaza yönüyle değil, aynı zamanda yaşanan küresel 1sınmada yerli ve dayanıklı türümüz olan meşenin daha dirençli olması, meşe meşcerelerinin daha fazla biyolojik çeşitliliğe imkân vermesi, daha fazla böcek, mantar ve yaban hayatına sahip olması göz önüne alınarak yapılmasıdır.

\section{Teşekkür}

Bu makale, Orman Genel Müdürürlüğü, Güneydoğu Anadolu Ormancılık Araştırma Enstitüsü Müdürlüğü tarafından yürütülen "Elazığ yöresinde meşe ekimlerinin gelişimi ile bazı yetişme ortamı özellikleri arasındaki ilişkiler" başlıklı bitirilen araştırma projesi sonucunda hazırlanan ve OGM Araştırma İhtisas Grupları Toplantısında yayınlanması yönünde karar verilen proje sonuç raporunun (Kalkan ve ark., 2020) özetidir. Projeye katkılarını esirgemeyen danışman hocamız Prof. Dr. Kürşad ÖZKAN'a, emeği geçen Güney Doğu Anadolu Ormancılık Araştırma Enstitüsü Müdürlüğü personeline ve Elazı̆̆ İşletme Müdürü Hidayet SARI'ya sonsuz teşekkürü borç biliriz.

\section{Kaynaklar}

Asutay, H.J., 1985. Baskil (Elâzı̆̆) çevresinin jeolojik ve petrografik incelenmesi: Doktora tezi (yayımlanmamış), A.Ü. Fen Fak. Jeoloji Müh. Bölümü, Ankara.

Auchmoody, L.R., Clay-Smith, H., 1979. Oak soil- Site relationship in Northwestern West Virginia. Forest service research paper NE-434.

Barbier, S., Gosselin, F., Balandier, P., 2008. Influence of tree species on understory vegetation diversity and mechanisms involved - a critical review for temperate and boreal forests. Forest Ecology and Management 254: $1-15$.

Berges, L., Chevalier, R., Dumas, Y., Frannc, A., Gilbert, J.M., 2005. Sessile oak (Quercus petraea Liebl.) site index variations in relation to climate, topography and soil in even-aged high-forest stands in northern France. Ann. For. Sci. 62 (2005) 391-402, (C) INRA, EDP Sciences, 2005, DOI: 10. 1051/ forest:2005035.

Berges, L., Balandier, P., 2010. Revisiting the use of soil water budget assessment to predict site productivity of sessile oak (Quercus petraea Liebl.) in the perspective of climate change. Eur J Forest Res (2010), 129:199-208. DOI: 10. 1007/s10342-009-0315-1.

Bernicchia, A., Benni, A., Venturella, G., Gargano,
M.L., Saitta, A., Gorjón, S.P., 2008. Aphyllophoraceous wood-inhabiting fungi on Quercus spp. in Italy. Mycotaxon 104: 445-448.

Beyarslan, M., 1996. Kömürhan Ofiyolit Birimi'nin Petrografik ve Petrolojik İncelenmesi. Firat Üniversitesi, Fen Fakültesi Enstitüsü, Jeoloji Mühendisliği Anabilim Dal1, Doktora Tezi, 103 s.

Bonfils, P., Horisberger, D., Ulber, M., 2005. Förderung der Eiche. Strategie zur Erhaltung eines Natur- und Kulturerbes der Schweiz. Schriftenreihe Umwelt Nr. 383. proQuercus; Bundesamt für Umwelt, Wald und Landschaft BUWAL, Bern.

Bowersox, T.W., Ward, W.W., 1972. Prediction of oak site index in the ridge and valley region of Pennsylvania. For. Sci. 18: 192-195.

Bre' da, N., Granier, A., 1996. Intra and inter-annual variation of transpiration, leaf area index and radial growth of a sessile oak stand. Ann Sci For 53: 521-536.

Bridge, MC., Gasson, PE., Cutler, DF., 1996. Dendroclimatological observations on trees at Kew and Wakehurst Place: event and pointer years. Forestry 69(3): 263-269, DOI: 10. 1093/ forestry/9.3.263.

Bronisz, A., Bijak, S., Bronisz, K., Zasada, M., 2012. Climate influence on radial increment of oak (Quercus sp.) in central Poland. Geochronometria 39(4): 276-284, DOI: 10. 2478/s13386-012-0011-7.

Caprio, E., Ellena, I., Rolando, A., 2009. Native oak retention as a key factor for the conservation of winter bird diversity in managed deciduous forests in northern Italy. Landscape Ecology 24: 65-76.

Carmean, W.H., 1961. Soil Survey Refinements Needed for Accurate Classification of Black Oak Site Quality in Southeastern Ohio. Soil Science Society of America Journal, 1961 - dl.sciencesocieties.org.

Carmean, W.H., 1965. Black oak site quality in relation to soil and topography in southeastern Ohio. Soil Sci. Soc. Am. Proc. 29: 308-312.

Carmean, W.H., 1970. Site quality for eastern hardwoods. In The silviculture of oaks and associated species. p./ 36-56. U.S. Dep. Agric. For. Serv. Res. Pap. NE-144.

Carmean, W.H., 1973. Forest soils bibliography for the North- Central Region. [Includes subject matter index through 1972. 1 U.S. Dep. Agric. For. Serv. Gen. Tech. Rep. NC-5. 68 p.

Carmean, W.H., 1975. Forest site quality evaluation in the United States. Adv. Agron. 27: 209-269. 
Cedro, A., 2007. Tree-ring chronologies of downy oak (Quercus pubescens), pedunculate oak (Q. robur) and sessile oak $(Q$. petraea) in the Bielinek Nature Reserve: Comparison of the climatic determinants of treering width. Geochronometria 26: 39-45, DOİ: 10. 2478 / v10003-007-0005-2.

Costa, A., Madeira, M., Oliveira, A.C., 2008. The relationship between cork oak growth patterns and soil, slope and drainage in a cork oak woodland in Southern Portugal. www.sciencedirect.com. Forest Ecology and Management 255 (2008) 1525-1535.

Çepel, N., Dündar, M., 1980. Bolu- Aladağ Orman Ekosistemlerinde Sarıçam'ın (Pinus sylvestris L.) Boy Art1mı ile Reliyef ve Toprak Özellikleri Arasındaki İliskiler, İ.Ü. Orman Fakültesi Dergisi, Seri A, Cilt 30, Sayı 1, 129-140.

Çepel, N., 1995. Orman Ekolojisi. İ.Ü. Orman Fakültesi. Üniversite Yayın No, 3886. Orman Fakültesi Yayın No, 433. ISBN 975-404-398-1.

de Rigo, D., Enescu, C.M., Durrant, H.T., Caudullo, G., 2016. Quercus cerris in Europe: distribution, habitat, usage and threats. https://www.researchgate.net/ publication/299471050. https://doi.org/10.1093/treephys/ tpn003. (Ziyaret tarihi: 02.10.2019).

Doležal, J., Mazůrek, P., Klimešová, J., 2010. Oak decline in southern Moravia: the association between climate change and early and late wood formation in oaks. Preslia 82(3): 289-306.

Douglass, A.E., 1941. Crossdating in Dendrochronology. Journal of Forestry 39: 825-831.

Ehrlich, P.R., Murphy, D.D., 1987. Monitoring populations on remnants of native vegetation. In: Nature conservation: the role of remnants of native vegetation (eds D. A. Saunders, G. W. Arnold, A. A. Burbidge \& A. J. M. Hopkins), pp. 201-210. Surrey Beatty \& Sons Pty Limited, Chipping Norton.

Eilmann, B., Zweifel, R., Buchman, N., Fonti, P., Ridling, A., 2009. Drought-induced adaptation of the xylem in Scots pine and pubescent oak. Tree Physiology 29, 1011-1020. DOI:10. 1093/treephys/ tpp035.

Einspahr, D., Mc-Comb, Al., 1951. Site Index Of Oaks In Relation To Soil And Topography İn Northeastern Iowa. Journal of Forestry 49: 719-723.

Fekedulegn, D., Hicks-Jr, R.R., Colbert, J.J., 2003. Influence of topographic aspect, precipitation and drought on radial growth of four major tree species in an Appalachian watershed. Forest Ecology and Management. 177: 409-425.
Fralish, J.S., 1994. The eff ect of site environment on forest productivity in the Illinois Shawnee Hills. Ecological Applications. 4: 134-143.

Frei, M., 2003. Die Baumflechten des Eichenwitwaldes von Wildenstein. Mitteilungen der Naturforschenden Gesellschaften beider Basel 7: 157-172.

Friedrichs, DA., Trouet, V., Büntgen, U., Frank, DC., Esper, J., 2009. Complex climate controls on 20th century oak growth in Central-West Germany. Tree Physiology, Volume 29, Issue 1, January 2009, Pages 39-51, https://doi.org/10.1093/treephys/tpn003.(Ziyaret tarihi: 04.10.2019).

Fritts, H.C., 1976. Tree rings and climate. Academic Press, London.

Gaiser, R.N., 1951. Relation between topography, soil characteristics, and the site index of white oak in southeastern Ohio, U.S. Dep. Agric. For. Serv., Central States For. Exp. Stn., Tech. Pap. 121. 12 p.

Gülçur, F., 1974. Toprağın Fiziksel ve Kimyasal Analiz Metodları, İ.Ü. Orman Fakültesi Yayınları, İ. Ü. Yayın No: 1970, O. F. Yayın No: 201, Kurtulmuş Matbaas1, İstanbul.

Gülsoy, S., Şentürk, Ö., Karakaya, F., 2016. Kunduz Yöresi (Vezirköprü) Ormanlarında Saçlı Meşe (Quercus cerris L.) Türünün Potansiyel Dağ 11 1m Modellemesi. Süleyman Demirel Üniversitesi, Fen Bilimleri Enstitüsü Dergisi. Cilt 20, Say1 2,281-289.

Güner, T.Ş., 2008. Bozkıra Geçiş Bölgesindeki Sarıçam (Pinus sylvestris L. ssp. hamata (Steven) Fomin.) Ormanlarının Gelișimi ile Bazı Yetişme Ortamı Özellikleri Arasındaki İlişkiler Orman Toprak Ve Ekoloji Araştırmaları Enstitüsü Müdürlüğü, Çeşitli Yayınlar Serisi No: 3.

Hannah, P.R., 1968. Topography \& Soil Relations For White and Black Oak in Southern Indiana. U.S. Forest Service Research Paper, N-25.

Irmak, A., 1954. Arazide ve Laboratuvarda Toprağın Araştırılması Metodları, İ.Ü. Yayınları, İ. Ü. Yayın No: 599, O. F. Yayın No: 27, İstanbul.

Johnson, P.S., Shifley, S.R., Rogers, R., 2009. The Ecology and Silviculture of Oaks. 2nd Edition. Website: www.cabi.org. ISBN-13: 9781845934743

Kabrick, J.M., Shifley S.R., Jensen, R.G., Larsen, D.R., Grabner, J.K., 2004. Oak Forest Composition, Site Quality, And Dynamics in Relation to Site Factors in the The Southeastern Missouri Ozarks. https://www.researchgate.net/publication/239616081.

Kalkan, B., Karakurt, H., Özkan, K., Tiryaki, O., Güneş, 
Ö., 2020. Elazı̆̆ Yöresinde Meşe Ekimlerinin Gelişimi ve Bazı Yetişme Ortamı Özellikleri Arasındaki İlişsiler. Orman Genel Müdürlüğü, GDA Ormancılık Araştırma Enstitüsü Müdürlüğü, Proje Sonuç Raporu: 24.1102

Kantarc1, M.D., 2000. Toprak İlmi. İ.Ü Orman Fakültesi Yayınları. İ.Ü. Yayın No: 4261, O.F. Yayın No: 462, İstanbul.

Kantarc1, M.D., 2005. Orman Ekosistemleri Bilgisi. İ.Ü. Orman Fakültesi Yayınları, İ.Ü. Yayın No: 4594, O.F. Yayın No: 488, İstanbul.

Kantarc1, M.D., 2010. Türkiye Ormanlarındaki Meşe Taksonlarının Yayıldığı Yetişme Ortamı Bölgeleri ve Bu Türlerin Ekolojik İstekleri The Oak Ecology-History Managemen and Plannning II, Bildiriler Kitab1 S.17, Süleyman Demirel Üniversitesi Orman Fakültesi 01-03 Haziran 2010 Isparta.

Karaöz, Ö., 2015. Verimliliğe Etki Eden Faktörler. İ.Ü. Orman Fakültesi. Toprak İlmi ve Ekoloji Ana Bilim Dalı. https://www.researchgate.net/publication/ 273456074. https://doi.org/10.1093/treephys/tpn003. (Ziyaret tarihi: 09.10.2019).

Karatepe, Y., Süel, H., Yetüt, İ., 2005. Isparta Gölcük Tabiat Parkı'nda Toros sediri (Cedrus libani A. Rich.)'nin Farklı Anakayalardan Oluşmuş Topraklardaki Gelişiminin Ekolojik İrdelenmesi. SDÜ Orman Fakültesi Dergi$s i$, Seri A, 1: 64-75.

Klute, A., 1986. Water Retention. In: Klute, A. (Ed.), Methods of Soil Analysis. Part 1. Physical and Mineralogical Methods, 2nd ed. ASA-SSA, Madison, WI, pp. 635-653.

Mahmoud, T., Talebi, KH. S., Goujani, H.J., 2006. Site Demands and Some Quantitative and Qualitative Characterisctics of Persian Oak (Quercus brantii L.) In Chaharmahal \& Bakhtiari Province (Western Iran). Iranian journal Of Forest and Poplar Research Spring, 2006, Volume 14, Number1(23); 67-79.

Oberhuber, W., Kofler, W., 2000. Topographic influences on radial growth of Scots pine (Pinus sylvestris L.) at small spatial scales. Plant Ecology 146: 231-240.

Olsen, S.R., Cole, V., Watanabe, F.S., Dean, L.A., 1954. Estimation of Available Phosphorus in Soils by Extraction with Sodium Bicarbonate, USDA.

Otieno, DO., Kurz-Besson, C., Liu, J., Schmidt, M., Do, R., David, TS., Siegwolf, R., Pereira, JS., Tenhunen, JD., 2006. Seasonal variations in soil and plant water status in a Quercus suber L. Stand: roots as determinants of tree productivity and survival in the Mediterranean-type ecosystem. Plant Soil 283:119-135.
Özkan, K., Gülsoy, S., Mert, A., 2006. Buldan Batı Dağlık Bölgesinde Saçlı Meşenin (Q. cerris L. var. cerris) Yayılışını Sınırlandıran Faktörler. Buldan Sempozyumu Bildirileri. Cilt.1, S:587-594.

Pausas, J.G., Blade, C., Valdecantos, A., Seva, J.P., Fuentes, D., Alloza, J.A., Vilagrosal, A., Bautista, S., Cortina, J., Vallejo, R., 2004. Pines and oaks in the restoration of Mediterranean landscapes of Spain: New perspectives for an old practice - a review. Plant Ecology 171: 209-220, 2004. (C) 2004 Kluwer Academic Publishers.

Peñuelas, J., Boada, M., 2003. A global change-induced biome shift in the Montseny mountains (NE Spain). Global Change Biology 9: 131-140.

Pilcher, JR., Gray, B., 1982. The relationships between oak tree growth and climate in Britain. Journal of Eco$\log y$ 70(1): 297-304, DOI: 10.2307/2259880

Polat, S., Polat, O., Kantarcı, D., Tüfekçi, S., Aksay Y., 2014. Mersin-Kadıncık Havzası'ndaki Sedir (Cedrus libani A. Rich.) ve Karaçam (Pinus nigra Arnold.) ağaçlandırmalarının boy gelișimi ile bazı yetişme ortamı özellikleri arasındaki ilişkiler. Ormancılık Araştırma Dergisi. 2014/1, A, 1:1, 22-37. DOI: http://dx.doi. org/10.17568/oad.86449

Rambal, S., 1984. Water balance and pattern of root water uptake by a Quercus coccifera L. evergreen scrub. Oecologia 62;18-25.

Ranius, T., Jansson, N., 2000. The influence of forest regrowth, original canopy cover and tree size on saproxylic beetles associated with old oaks. Biological Conservation 95: 85- 94.

Rohner, B.E., 2012. Growth and mortality of oak ( $Q u-$ ercus spp.) A combined analysis of monitoring and treering data from Swiss forest reserves. research- collection. ethz. ch. https://doi.org/10.3929/ethz-a-007594406. (Ziyaret tarihi:14.03.2019).

Rosenberg, N.J., Blad, B.L., Verma, S.B., 1983. Microclimate - the biological environment. 2nd ed. New York, NY: Wiley. 528 p.

Russell, T.E., 1971. Seeding And planting Upland Oaks. Oak symposium proceedings. https://www.nrs.fs.fed. us/ pubs/other/oak_sym/. https://doi.org/10.1093/ treephys/tpn003. (Ziyaret tarihi: 03.10.2019).

Saraçoğlu, N., Kantarcı, M.D., 1999. Bartın Yöresi Sapl1 Meşe (Quercus robur L.) Baltalıklarında Büyümeyi Etkileyen Arazi ve Toprak Özellikleri, TÜBİTAK, Tarım Orman ve Gıda Teknolojileri Araştırma Grubu, Proje No: TARP-2141, Bartın, S:48

Scharn-Weber, T., Manthey, M., Criegee, C., Bauwe, 
A., Schröder, C., Wilmking, M., 2011. Drought matters - declining precipitation influences growth of Fagus sylvatica L. and Quercus robur L. in north-eastern Germany. Forest Ecology and Management 262(6): 947-961, DOI: 10. 1016/ j.foreco.2011.05.026.

Şentürk Ö., Gülsoy, S., Tümer, İ., 2014. Aydınca Yöresi (Amasya) Ormanlarında Saçlı Meşe (Quercus cerris L.) Türünün Dağılımı ile Yetişme Ortamı Özellikleri Arasındaki İlişkiler. Mehmet Akif Ersoy Üniversitesi Fen Bilimleri Enstitüsü Dergisi; Cilt: 5 Sayı: 2; 13-21.

Sevim, M., 1960. Bazı Önemli Orman ve Kültür Ağaçlarının Yetişme Muhiti Münasebetleri Hakkında Genel Bilgiler. İ.Ü. Orman Fakültesi Dergisi, Seri B, Cilt 10, Sayı 1.

Sherrod, P.H., 2014. DTREG Predictive and Modelling Software at www.dtreg.com

Shostak, D.I., Loewenstein, E.F., Dubois, M.R., 2004. Topographic Position and Site Index: An Oak Regeneration Relationship. Gen. Tech. Rep. SRS-71. Asheville, NC: U.S. Department of Agriculture, Forest Service, Southern Research Station. pp. 243-248

Sohar, K., Helema, S., Laanelaid, A., Raisio, J., Tuomenvirta, H., 2013. Oak Decline in a Southern Finnish Forest as Affected by a Drought Sequence. Geochronometria, 41(1) 2013: 92-103. DOI: 10. 2478/s13386-013-0137-2.

Stokes, M.A., Smiley, T.L., 1968. An introduction to treering dating. The University of Chicago Press, Chicago.

Talebi, S., Bordbar, K., Pur, H.K., Parvar P.M., 2009. Site Demands of Some Forest Tree Species (Q. brantii L.) in Fars Province. AGRIS- agris.fao.org/agris/search/ https://doi.org/10.1093/ treephys / tpn003. (Ziyaret tarihi: 01.10 .2019$)$

Tesch, S.D., 1981. The evolution of forest yield determination and site classification. Forest Ecology and Management 3: 169-182.

Trimble-Jr, G.R., Weitzman, S., 1956. Site index studies of upland oaks in the northern Appalachians. Forest Science. 2: 162-173.
Urbieta, I.R., Garcia, L.V., Zavala, M., Maranon, T., 2011. Mediterranean pine and oak distribution in southern Spain: Is there a mismatch between regeneration and adult distribution?. Journal of Vegetation Science 22 (2011) 18-31.

Yaltırık, F., 1984. Türkiye Meşeleri Teşhis kılavuzu İ.Ü. Orman Fakültesi. Yenilik Basımevi, İstanbul.

Yawney, H.W., 1964. Oak site index on Belmont limestone soils in the Allegheny Mountains of West Virginia. U.S. Dep. Agric. For. Serv. Res. Pap. NE-30. 16 p.

Yawney, H.W., Trimble-Jr, G.R., 1968. Oak soil-site relationships in the ridge and valley region of West Virginia and Maryland. U.S. Dep. Agric. For. Serv. Res. Pap. NE96. $19 \mathrm{p}$.

Weber, P., Bugmann, H., Rigling, A., 2007. Radial growth responses to drought of Pinus sylvestris and $Q u$ ercus pubescens in an inner-Alpine dry valley. Journal of Vegetation Science 18: 777-792.

White, D.P., 1958. Available water: the key to forest site evaluation. In: Proceedings, 1st forest soils conference. East Lansing, MI: Michigan State University Agricultural Station: 6-11.

Wilcox, B.A., 1984. In situ conservation of genetic resources: determinants of minimum area requirements. In: National parks, conservation, and development: the role of protected areas in sustaining society (eds J. A. McNeely \& K. R. Miller), pp. 639-647. Smithsonian Institution Press, Washington.

Zang, C., Pretzsch, H., Rothe, A., 2012. Size-dependent responses to summer drought in Scots pine, Norway spruce and common oak. Trees - Structure and Function 26(2): 557-569, DOI 10. 1007/ s00468-011-0617-z

Zech, W., Çepel, N., 1972. Güney Anadolu'daki Bazı Pinus brutia Meşcerelerinin Gelişimi ile Toprak ve Relief Özellikleri Arasındaki İlişkiler, İstanbul Üniversitesi Yayın No: 1753, Orman Fakültesi Yayın No: 191, İstanbul, $107 \mathrm{~s}$. 